\title{
Learning Model Jurisprudential Inquiry to Improve Critical Thinking of MTs N 1 Situbondo Students
}

\author{
Lailatul Badriyah ${ }^{1, a^{*}}$, Warsono $0^{1, b}$, and Ali Haidar ${ }^{1, c}$ \\ ${ }^{1}$ Social Studies Program, Postgraduate Program, State University of Surabaya, East Java, Indonesia \\ a lailabi17@gmail.com; b warsono@unesa.ac.id; c m.alihaidar@ymail.com \\ ${ }^{*}$ Corresponding Author \\ Whatsapp number: [085216622951]
}

How to Cite : Badriyah, L., Warsono, W., Haidar., A. (2020). Learning Model Jurisprudential Inquiry to Improve Critical Thinking of MTs N 1 Situbondo Students. International Journal for Educational and Vocational Studies, 2 (1), 115-120. DOI: https://doi.org/10.29103/ijevs.v2i1.2064

\section{ARTICLE HISTORY}

Received: 30 Novemer 2019

Revised: 16 December 2019

Accepted: 16 January 2020

\section{KEYWORDS}

Jurisprudential Inquiry Model; Critical Thinking;

\begin{abstract}
The Jurisprudential Inquiry learning model is a learning model in its application facilitating learners to be sensitive to social problems, take a position on the problem, and maintain that position / attitude with relevant and valid arguments so as to improve students' critical thinking skills. Critical thinking in this research refers to five indicators, namely the ability to form conclusions, formulate questions, uncover problems, formulate alternative solutions. The purpose of this study was to determine the effect of Jurisprudential Inquiry learning model on critical thinking skills of MTs N 1 Situbondo students. This study uses experimental research design with the form of Quasi-Experimental Design with the type of pretest posttest control group design. The sample in this study was class VIII G numbering 22 students and VIII H a number of 24 students with purposive sampling sampling technique. The technique of collecting data uses test questions with the description form. The data analysis technique in this study is to use the independent sample t-test. The results of this study indicate that there is a significant influence on the use of the Jurisprudential Inquiry learning model on students' critical thinking with indicators formulating conclusions, formulating questions, expressing problems and providing alternative solutions. The results of the hypothesis test show tcount 3.362 and table with a significance level $(5 \%) 0.05$, degree of freedom $(\mathrm{db})=(\mathrm{n}-2)$ then obtained $\mathrm{t}_{(0.05)}(44)$ table $=2.015$. The results of tcountstable, which shows the results of $3.362>2.015$. As for the significance level of $5 \%(0.05)$ has a significance value $a>0.05$, i.e. (2-tailed) $0.694>$ 0.05 ., it can be concluded that thelearning model is Jurisprudential Inquiry more influential than themodel Problem Solving on the critical thinking ability of students on the material emergence of national organizations and the growing spirit of nationalism.
\end{abstract}

\section{INTRODUCTION}

The 2013 curriculum emphasizes that learning activities are an educational process that provides opportunities for students to develop their potential to become increasingly good abilities in the attitudes, knowledge, and skills needed for themselves to live and to be social, national and take part in the welfare of the lives of the people humans (Saefuddin and Berdiati, 2016: 8-9).

Closely related to the learning process, students need to have thinking skills as capital in the face of social development and knowledge in the community. In addition, the students' thinking skills are a means to an educational goal, so that students are able to solve high level problems. Less learning that actively involves students can inhibit thinking skills (Nasution 2006: 171). According to Zamroni and Mahfudz in Suprijono (2016: 29) improving critical thinking skills can be done in four ways, namely the application of certain learning models, the task of critiquing books, the use of stories and the use of the Socratic question model.

Partini (2016) revealed that students' thinking skills in social studies learning were influenced by the use of conventional methods which tended to place teachers at the center of information and the lack of variation in learning methods. The situation has an impact on the low interest, enthusiasm, and activeness of student learning so that social studies learning achievements include mastery of socialknowledge, motivation and certainattitudes, skills in critical and reflective thinking in decision making and problem solving (skill) is also low. 
Uno (2009: 30) explains that school is a formal pathway that has the responsibility to create an intelligent generation and is able to think critically, namely the ability to overcome conflicts or problems faced by both themselves and the surrounding community. Critical and creative thinking skills help students understand problems systematically, deal with various obstacles in an organized way, formulate questions and design appropriate solutions to existing problems (Muspita, Lasmawan, Sariasa, 2013). Setyorini, Sukiswo, Subali (2011) explained that increasing students' critical thinking skills can be influenced by the application of learning models that can train students to think critically.

Laksono (2013) explains that in the 2013 curriculum the ability to think critically, creatively, collaboratively and be able to communicate well will improve one's character, so that the knowledge and competencies he masters will make someone have an attitude / character that is responsible, hard working, honest in his life. Critical thinking becomes a priority in an education system as a provision of students' abilities to deal with various changes in life.

Thinking skills are one part of a number of social competencies that need to be developed (Sardiman, 2010). The social studies curriculum emphasizes critical thinking skills as a competency that must be achieved by students. Critical thinking is part of the basic intellectual abilities related to the development of students' identities as thinking creatures whose power to receive and process and build their knowledge, values and attitudes, and actions both in their personal and social lives. The ability to identify social problems, formulate social problems and solve problems as an important characteristic in the ability to think. Closely related to the learning process of the teacher as a facilitator must have the ability to choose effective learning models to improve students' critical thinking skills in order to create an atmosphere of effective, conducive and enjoyable learning.

The selection of the right learning model by the teacher can help students have critical thinking skills, one of which is the jurisprudential or Jurisprudential Inquiry model pioneered by Donald Oliver and James P. Shaver. The application of themodel is Jurisprudential Inquiry used as an alternative to train student activities in learning to demonstrate skills as well as critical thinking skills.

Huda (2016: 124) explains that the learning model Yurisprudentian Inquiry influences the ability of students to conduct a systematic analysis of social issues as the main direct learning outcomes. This ability includes skills in identifying public issues, applying social values, using analogies to explore issues, and the ability to identify and solve definitions, facts, and values in a particular problem. The ability to dialogue dynamically with other people is another result that is also quite important. Themodel Jurisprudential Inquiry can also educate students' capacity to be involved in solving social issues and stimulate their desire to take positive social actions.

Based on observations made in the social studies learning process and interviews with students in MTs N 1 Situbondo and teachers, students tend to be passive in learning because more listening to lectures delivered by teachers, students' ability to answer high-level questions or problem solving needs to be developed this can be seen from the learning achievements of students under $75 \%$ or below the KKM.

Such learning conditions also affect the ability of students to think critically in social studies learning, especially in class VIII (eight) students. Students are passive in learning because they only tend to listen to the teacher's explanation, resulting in a lack of mastery of concepts. Learning material received is only limited to adding knowledge but still does not understand the urgency of applying this knowledge in addressing various problems that occur in the environment. The low student interest in learning in social studies and the lack of skill development have an impact on students' ability to develop critical thinking skills.

Based on the background explanation above and given the importance of developing critical thinking as part of 21st Century skills that must be mastered to equip students to face various changes in life, the main objective in this study is to improve the critical thinking skills of MTs N 1 Situbondo students in social studies learning with the use of thelearning model Jurisprudential Inquiry in the material for the emergence of movement organizations and the growth of a national spirit.

Referring to the background, problem identification, and problem limitation described above, the problem formulation can be formulated as follows.1) Is the learning model Jurisprudential Inquri better than the learning model Problem Solving in improving the critical thinking skills of MTs N 1 Situbondo students on the emergence of organizational movements and the growing spirit of nationalism?. 2) How big the difference in the results using the learning model Jurisprudential Inquri compared to using the model Problem Solving in improving critical thinking skills of MTs N 1 Situbondo students on the emergence of organizational movements and the growth of nationalism?

\section{METHODS}

This study uses an experimental research design with the form of Quasi Experimental Design. The type used in this experiment is Pretest Posttest Control Group Design. In this research design there are two groups of subjects namely the experimental group and the control group whose selection is carried out randomly. Samples were taken as many as 44 students, namely in class VIII G totaling 22 students and class VIII H totaling 24 students in MTs N 1 Situbondo.

\subsection{Definition of Model Learning Jurisprudential Inquiri}

Model learning Jurisprudential Inquiry is a part of social 
learning model clump, clump where social learning model gives priority to the improvement of skills of learners relate to others, adaptive in the life of a democratic society, and active participation. The social family learning model encourages students to enter the real nuances in which social problems are faced every day and students learn to overcome their own problems. The social family learning model aims to develop the cooperative / cooperative ability of students (Suprijono, 2016: 67).

\subsection{Syntax Learning Model Jurisprudential Inquiry}

Learning Model Jurisprudential Inquiry has the following syntax.

1. Case Orientation

2. Identifying the issue

3. Taking a position (attitude)

4. Exploring the attitude that underlies the attitude taking

5. Establishing and qualifying attitudes

6. Test assumptions about facts, definitions, and consequences.

\subsection{Indicators of Critical Thinking}

According to Ennis in Costa (1985: 16) explains that there are 12 indicators of critical thinking that are grouped into 5 groups of thinking skills, namely providing simple explanations (elementary clarification), building basic skills (basic support), concluding (interfence), making further explanation (advance clarification), and strategy and tactics (strategy and tactics).

\subsection{Statistical Data Analysis}

The data analysis technique in this study is to use the independent sample t-test.

\section{RESULTS AND DISCUSSION}

\section{Results}

\subsection{Pretest and Posttest Student's Critical Thinking Skill}

The result of the pretest and postest student's critical thinking skill can be seen in table 1 .

Table 1. Description Statisticsresults for pretest and posttest Critical Thinking Ability Students in Control Class and Eksperiment Class

\begin{tabular}{ccccc}
\hline & N & MIN & MAX & 80 \\
\hline Pretest Eksperiment Class & 70,42 & 40 & 90 & 24 \\
\hline Posttest Eksperiment Class & 81,25 & 60 & 80 & 97 \\
\hline Pretest Control Class & 71,36 & 60 & 80 & 22 \\
\hline Posttest Control Class & 74,55 & 60 & 80 \\
\hline
\end{tabular}

Based on table 1 the results of the descriptive analysis of students' critical thinking abilities pretest before being given the treatment of thelearning model Jurisprudential Inquiry in the experimental class and thelearning model Problem Solving in the control class show the average value of the experimental class pretest namely 20.42 , standard deviation 9.079 , minimum value of 40 , and a maximum value of 80 . The control class obtained an average value of 71.36 , a standard deviation of 7.102, a minimum value of 60 , and a maximum value of 80 .

Table 2. Test Result Independent Sample t-test Initial Values of Research Critical Thinking Ability Test (Pretest)

\begin{tabular}{cccccc}
\hline & Mean & T & Df & Sig.(2-tailed) & Mean Difference \\
\hline Control Class & Eksperiment Class & & & & \\
\hline 71,36 & 70,43 & $-0,391$ & 44 &, 697 & $-0,947$ \\
\hline
\end{tabular}

Based on table 2 the results of the descriptive analysis of posttest students' critical thinking ability after receiving treatment of thelearning model Jurisprudential Inquiry in the experimental class andlearning model Problem Solving in the control class show the average value of the experimental class posttest 81.25 , a standard deviation of 6.797, a minimum value of 60 , and a maximum value of 90 . In the control class an average value of 74.55 is obtained, a standard deviation of 6.710 , a minimum value of 60 , and a maximum value of 80 .

\subsection{Independent Sample t-test Pretest Critical Thinking}

Test hypothesis research initial test students' critical thinking skills (pre-test) are Ho = There is no significant difference in the ability to think critically between the experimental class and the control class $\mathrm{H}_{1}$ : There is a 
significant difference in critical thinking skills between the experimental class and the control class. This hypothesis test is conducted before students get treatment, where the experimental class class gets treated with thelearning model Jurisprudential Inquiry and the control class using themodel Problem Solving.

Based on SPSS output 16.00 on the table it is known thattvalue the of -0.391 and $t_{\text {table }}$ with a significance level (5\%) 0.05 , degree of freedom $(\mathrm{db})=(\mathrm{n}-2)$, the obtained $\mathrm{t}_{(0: 05)}(44)$ table

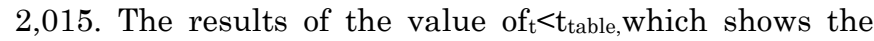
results $-0.391<2.015$. As for the significance level of $5 \%$ (0.05) has a significance value $\alpha>0.05$, i.e. (2-tailed) $0.697>$ 0.05 . So it can be concluded that there is no significant difference in the ability to think critically between the

Table 3. Test Result Independent Sample t-test Vinal Values of Research Critical Thinking Ability Test (Posttest)

\begin{tabular}{cccccc}
\hline & Mean & T & Df & Sig.(2-tailed) & Mean Difference \\
\hline Control Class & Eksperiment Class & & & & \\
\hline 74,55 & 81,25 & 3,362 & 44 &, 003 & $-0,947$ \\
\hline
\end{tabular}

experimental class and the control class before being given treatment, meaning that between the experimental class and the control class students have critical thinking skills that are not much different at the time of the pretest. This is reinforced by the average experimental class getting a value of 70.43 and the average control class has a value of 71.36 .

\subsection{Independent Sample t-test Posttest Critical Thinking}

This hypothesis test is conducted after students get treatment, where the experimental class class gets treated with thelearning model Jurisprudential Inquiry and the control class using themodel Problem Solving.
Based on SPSS output 16.00 on the table it is known thatt value the of 3.362 and table with a significance level (5\%) 0.05 , degree of freedom $(\mathrm{db})=(\mathrm{n}-2)$, the obtained $\mathrm{t}_{(0: 05)}(44)$ Table $=2,019$. The results of $t_{\text {count }}>t_{\text {table, }}$ which shows the results of $3.362>2.019$. As for the significance level of $5 \%$ (0.05) has a significance value $\alpha>0.05$, i.e. (2-tailed) $0.003>$ 0.05 , so if consulted with a significance level of 0.025 (1-tailed) shows a significance value of $\alpha>0.025$, i.e. $0.347>$ 0.025 . So it can be concluded that there are significant differences in the ability to think critically between the experimental class and the control class after being given treatment, meaning that between the experimental class and control class students have critical thinking skills that are not the same at the time of the posttest. This is reinforced by the experimental class obtaining an average value of 81.25 and the control class having an average value of 74.55 .

Thus it can be concluded that the use of thelearning model Jurisprudential Inquiry has better influence and effectiveness than the use of thelearning model Problem Solving on the critical thinking abilities of students on the emergence of organizational movements and the growth of the national spirit.

This study aims to determine the magnitude of the effect of the results of critical thinking skills on students in the experimental class group who were treated using thelearning model Jurisprudential Inquiry and the treatment using themodel Problem Solving in the control class. To determine this effect, the observations or observations and initial data collection were carried out with pretest and final data with posttest in the experimental class and the control class with material on the emergence of organizational movements and the growth of the national spirit.

The results of the descriptive statistical analysis of the initial data of the written test of students' critical thinking skills (pretest) in the material of the emergence of movement organization and the growth of the spirit of nationalism in the experimental class and the control class showed not too much difference. Where the pretest value of the experimental class was 71.42 and that of the control class was 71.36. While the posttest mean score of the experimental class was 81.25 and the control class was 74.55 .

Descriptive analysis results show that the research class, both the experimental class and the control class have a pretest value that is not too far away. The value obtained at the time of the pretest is because students do not yet have full knowledge of the material to be studied. Students are able to work on several questions but the answers are wrong. While it was different at the time of the post-test implementation when the students had obtained the material provided by the teacher, both classes both had an increase in the average value of the post-test. The difference is the amount of increase in post test mean values is different between the experimental class and the control class, where the experimental class has a higher mean value than the control class.

The results of the t-test of the research data were carried out to determine the difference between students' critical thinking skills before applying thelearning model Jurisprudential Inquiry in the experimental class and themodel Problem Solving in the control class, the value of $\mathrm{t}_{\text {count }}$ was -0.391 and the $t_{\text {table }}$ with significance level (5\%) 0 , 05 , degree of freedom $(\mathrm{db})=(\mathrm{n}-2)$, we get $\mathrm{t}_{(0.05)}(44)$ table $=2.015$.

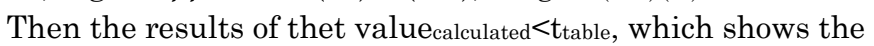
results $-0.391<2.015$. As for the significance level of $5 \%$ (0.05) has a significance value $\alpha>0.05$, i.e. (2-tailed) 0.697> 0.05 . So it can be concluded that there is no significant difference in the ability to think critically between the experimental class and the control class before being given treatment, meaning that between the experimental class 
and the control class students have the critical thinking ability not much different at the time of the pretest.

After being given treatment, where the experimental class is given thelearning model Jurisprudential Inquiry in the experimental class and themodel Problem Solving in the control class is obtained $t_{\text {count }}$ of 3.362 and $t_{\text {table }}$ with a significance level (5\%) 0.05, degree of freedom $(\mathrm{db})=(\mathrm{n}-2)$ then we get $t_{(0.05)}$ (44) table $=2.015$. The results of $t_{\text {count }}>t_{\text {table, }}$ which shows the results of $3.362>2.015$. As for the significance level of $5 \%(0.05)$ has a significance value $a$ $<0.05$, i.e. ( 2 -tailed) $0.003<0.05$. So it can be concluded that there is a significant difference in the ability to think critically between the experimental class and the control class after being given treatment, meaning that between the experimental class and the control class students have critical thinking skills that are not the same at the time of the posttest in other words the results of the critical thinking abilities of the experimental class after being treated with thelearning model Jurisprudential Inquiry better than the control class using themodel Problem Solving.

The results of these significant differences are also in accordance with previous studies, as conducted by Frida Intan Permatasari \& Rr. Nanik Setyowati (2016) with the title "The Effect of Inquiry Model Jurisprudence on PPKn Subjects on Increasing the Critical Thinking Ability of Class XI Students at SMA N Wonoayu". The results showed a significant effect evidenced by differences in student learning outcomes achieved through tests with open-ended question form form between the experimental class using the Inquiry Learning Jurisprudence learning model and the control class not using the Inquiry Jurisprudence learning model. Student activities during the learning process in the experimental class are more active than the control class. Experimental class students are able to reason and be critical in answeringquestions posttest based on indicators in thegrid posttest so that the inquiry Jurisprudence learning can improve students' critical thinking skills.

The difference in the results of the critical thinking ability test results between students of the experimental class using themodel Jurisprudential Inquiry and the control class using themodel is Problem Solving possible because each treatment has a characteristic in its application. Thelearning model is Jurisprudential Inqury designed to foster students' critical thinking skills through the stages of systematic stages which include the stage of case orientation, identifying issues, choosing positions, exploring attitude or argumentation and exploratory arguments, affirming and qualifying positions, testing factual assumptions behind qualified positions so that demanding students find their own experience based on social problems, especially about the issues of nationalism that exist in Indonesian society.

Through the stages contained in thelearning model Jurisprudential Inqiury, problems in learning materials that are adapted to learning material are problems that stimulate students to think critically and find solutions to problem solving. Students are required to find as many solutions as possible to a social problem about the issues of nationalism that occur in society and then make decisions about the most appropriate solution to be applied. This certainly requires students to think critically and find alternative solutions to a problem and make students have real learning experiences. If students are active in finding their own information, concepts, and generalizations, then what has been determined directly will always be remembered and understood by students.

Students certainly cannot follow the existing methods or steps automatically available in their minds. So that it takes steps and stages of completion that can be taken systematically and directed, in this there is alearning model Jurisprudential Inquiry. where, in this case the teacher is in the position as a facilitator who guides and creates a conducive atmosphere for students to arrive at their own learning experiences. The teacher must also be able to accommodate a variety of ongoing dialogue with students.

Thus it can be concluded that the use of thelearning model Jurisprudential Inquiry has better influence and effectiveness than the use of thelearning model Problem Solving on the critical thinking abilities of students on the emergence of organizational movements and the growth of the national spirit.

The usefulness of the application of thelearning model Jurisprudential Inquiry in social studies learning is part of the social family learning model, where the social family learning model gives priority to improving students' skills in dealing with others, adaptive in the life of a democratic society, and active participation. The social family learning model encourages students to enter the real nuances in which social problems are faced every day and students learn to overcome their own problems.

Huda (2016: 109) explains that the learning model in the social family category emphasizes the relationship of individuals with society and others. The main goal is to help students learn to work together, identify and solve problems, both academic and social in nature.

The learning model Jurisprudential Inquiry has several advantages including 1) motivated students to actively analyze cases, 2) encourage students' ability to debate and give arguments, 3) develop openness and tolerance for differences of opinion; 4) enrich students' knowledge about a case. Based on these advantages and proven by the results of hypothesis testing in this study, thelearning model Jurisprudential Inquiry is one of the learning models that provides alternative solutions to improve students' critical thinking skills.

\section{CONCLUSION}

Based on the results of the hypothesis test, it was concluded that there were significant differences between students who were treated using thelearning model Jurisprudential Inquiry and students who were treated 
using thelearning model Problem Solving on the material for the emergence of movement organizations and the growth of the national spirit. This is because as part of the social learning modellearning model Jurisprudential Inqiury has advantages and systematic syntax regarding the steps in addressing various actual issues relating to social problems that occur in society.

\section{REFERENCES}

Huda, Miftahul. (2016). Model-Model Pengajaran dan Pembelajaran, Isu-isu Motodis dan Paradigmatis. Yogyakarta: Pustaka Pelajar.

Huda, Miftahul. (2014). Model-Model Pengajaran dan Pembelajaran. Yogyakarta: Pustaka Pelajar.

Muspita, Z., Lasmawan, W., \& Sariyasa, S. (2013). Pengaruh Model Pembelajaran Berbasis Masalah Terhadap Kemampuan Berfikir Kritis, Motivasi Belajar, dan Hasil Belajar IPS Siswa Kelas VII SMPN 1 Aikmel (Doctoral dissertation, Ganesha University of Education).

Nasution. (2006). Berbagai Pendekatan dalam Proses Belajar Mengajar. Jakarta: Bina Aksara.

Saefuddin, H. Asis. Berdiati, Ika. (2016). Pembelajaran Efektif. Bandung: PT. Remaja Rosdakarya.

Sardiman A.M. (2010). Revitalisasi peran pembelajaran IPS dalam pembentukan karakter bangsa. Cakrawala Pendidikan, Th. XXIX, Edisi Khusus Dies Natalis UNY, 147-167. Diperoleh dari https://eprints.uny.ac.id /3554 /1/11 Sardiman_EDIT.pdf

Suprijono, Agus. (2016). Model-model Pembelajaran Emansipatoris. Yogyakarta: Pustaka Belajar.

Setyorini, Sukiswo, Subali. (2011). Penerapan model problem based learning untuk meningkatkan kemampuan berpikir kritis siswa SMP. Jurnal Pendidikan Fisika Indonesia (7), 52-56. Diperoleh dari http://journal.unnes.ac.id/ nju/index.php/JPFI/article/view/1070

Uno, H.B. (2009). Model pembelajaran menciptakan proses belajar mengajar yang kreatif dan efektif. Jakarta: Bumi Aksara. 